\title{
AIMS SETTING PROCESS OF PRE-SERVICE PRIMARY SCHOOL TEACHERS' FOREIGN LANGUAGE COMMUNICATIVE COMPETENCE DEVELOPMENT
}

\section{T. Bondar}

The article highlights the features of aims setting process of pre-service primary school teachers' foreign language communicative competence development, which is based on the definition of the purposes in accordance with the peculiarities of future professional activity. This process is one of the main educational categories and reflects the features of the educational process and the results of professional training of intending primary school teachers.

The paper focuses on the views of Ukrainian and foreign scientists on the types of aims and their functions in the future teachers' training.

This work aimed to outline the features of the aims setting process and to determine the purposes of pre-service primary school teachers' foreign language communicative competence development.

The process of determining the purposes of education is to form a system of general scientific and special professional knowledge that provides certain skills of intending primary school teachers. It is noted, that the main requirements for formulating the aims of the educational process are: clarity, hierarchy and diagnostics.

The competence orientation to general (broad sphere of life), special (narrow sphere of activity) and subject (certain courses) determines three stages of designing the aims of intending primary school teachers' foreign language communicative competence formation: establishing strategic (general) aim, concretizing it in tactical purposes and forming operational objectives. Tactical purposes are represented by a set of cognitive, developmental and implementation ones, which are specified by operational objectives. To schematically depict the hierarchy of the aims for the pre-service professionals' foreign language communicative competence development, the method "Aim Tree" was used, which allows to display the hierarchical structure of the aims by dividing the overall aim (level 1) into subaims (level 2), which in turn are divided into new sub-aims (level 2)

Keywords: aims setting, professional training, development process, foreign language communicative competence, preservice primary school teachers

This is an open access article under the CC BY license (http://creativecommons.org/licenses/by/4.0).

\section{Introduction}

A remarkable feature of modern Ukrainian education is renewing the educational sphere, that is determined by the insufficient compliance of its current state with the fleeting demands of society; a surge of bilingualism, intercultural communication, the main means of which is foreign language communicative competence; lingual globalization phenomena; labor market demand, which is not taken into account in the system of training future specialists in the field of primary education; lagging behind global educational trends; total informatization of all spheres of society and the unwillingness of future teachers to organize the educational process, based on information technology; low level of competence of teachers to introduce integrated approaches in the foreign language educational process of primary school.

Intending primary schools teachers' foreign language communicative competence is a part of their professional competence structure and the process of their foreign language communicative competence building determines its outcome in advance. The purpose as a system-forming component of professional training regulates the educational process and determines the methods of its implementation. So, the issue of aims setting process of intending primary school teachers' foreign lan- guage communicative competence development is important nowadays.

\section{Literature review}

The aims of professional training, according to T. Lazareva [1], are set in accordance with the final learning outcomes and are reflected in the content of education. The scientist emphasizes that nowadays the project of training aims should reflect: educational, developmental and upbringing components of the process of future specialists' professional development; hierarchical system of elements at different levels of subordination; the structure of future professional activity; to be aimed at forming a creative professional personality, as well as the personal and business qualities and creative abilities, necessary for future professional activity. The learning objectives are defined as the expected application of the acquired competencies by the graduates.

Designing the content of intending professionals' foreign language communicative competence developing is based on aims defining, i.e. setting goals in accordance with the features of future professional activity, which is one of the main educational categories and reflects the results of intending teachers' training and determines the educational process peculiarities. 
The issue of purposes substantiation of preservice specialists' professional training is covered in many researches, in particular M. Halliday considers educational purposes, based on the aspects of language learning [2], T. Konovalenko and O. Honcharova believe that educational content determines the learning objectives of developing pre-service English Teachers' communicative competence in the methodology course [3], D. Levites distinguishes goal-vectors and goal-results in the professional training [4], V. Radkevych identified six levels of aims: the overall aim, sub-aims, strategic aims, intermediate aims, operational aims; the ultimate aim [5].

The Ukrainian researcher S. Nikolaeva [6] notes that the aims of learning a foreign language and culture is a pre-planned result of educational activities, which is achieved through content, methods, teaching aids etc. Therefore, the purpose is the main component of the system of intending primary schools teachers' foreign language communicative competence developing, which is formed under the influence of the social order of society and influences the choice of other components of the system.

It should be noted, that in terms of the new competence methodology of educational programs, purposes are formulated as learning (program) outcomes. A learning outcome is a set of knowledge, skills, abilities, other competencies, acquired by a person in the process of learning a certain educational and professional or educational and scientific program that can be identified, quantified and measured; they are considered as the final results of the learning process, planned by the teacher [7]. Their development is a hierarchical process, where the program results of the highest level are reflected in the standards of higher education in Ukraine for the certain specialties, and at the next levels are mutually agreed program results for educational components, which ensure systematic and purposeful educational process.

Various kinds of purposes have been widely studied in pedagogical theory and practice. In particular, D. Levites [4] distinguishes goal-vectors and goalresults: the first are aimed at self-actualization, selfdetermination and personality development of an intending specialist, the second kind of aims gradually directs the educational process to the planned outcome, while goal-vectors can initially act as the end result. The challenge is to set the right priorities in setting goals. D. Levites notes that this problem can be solved by building a single system of aims of the educational process.

Focusing on the subject structure of the education content, I. Malafiik [8] identifies general and specific subject purposes. General purposes, according to the scientist, are achieved during the study of all the courses and are aimed at forming a holistic harmonious personality. They are characterized by a clear hierarchy: the level of society - the level of educational institution - the level of a course. The general purposes of the highest level of the hierarchy are a kind of guidelines that are specified in the goals of the lower levels. The specific subject purposes are realized in the classes of specific courses (subjects). They are determined by the categories of experience expression: knowledge, skills, abilities, emotional and value norms and the ways of creative activity [8].
In the process of studying the theoretical and methodological foundations of professional training in art vocational education institutions, the Ukrainian researcher V. Radkevych identified six levels of aims: the overall aim ensures the cultural and educational ideal formation and the professionally important qualities development; sub-aims that in close cooperation contribute to the development of competence, educational, upbringing and developmental components; strategic aims contain a set of such goals (competence, functional, technological, activity, communicative and educational); intermediate aims of specialists' professional training are aimed at mastering modern technologies; operational aims: near and far (are implemented during lectures and practical (laboratory) classes, in extracurricular activities); the ultimate aim [5].

The results of the researchers' views analysis allow us to say that many hypotheses regarding the studied issue appear to be debatable and questionable. Moreover, there is still a need to outline the problems of aims setting of intending primary school teachers' foreign language communicative competence development in the light of modern requirements to the primary school teachers for New Ukrainian School.

\section{The aim and objectives of the study}

The aim of this study is to determine and introduce the process of aims setting of intending primary school teachers' foreign language communicative competence development. been set:

To accomplish the aim, the following tasks have

1) to define the basic requirements for the aims formulation;

2) to describe the process of aims setting of intending primary school teachers' foreign language communicative competence development;

3) to present the hierarchy of educational aims development for the intending primary school teachers foreign language communicative competence schematically.

\section{Materials and methods}

The results of the analysis of researchers' views allow us to say that most of them consider it appropriate to formulate the aims of professional training through the educational (learning) results, as this method is characterized by a high level of instrumentality. Since learning outcomes are expressed in the actions of students, the teacher can diagnose them. Achieving the results of professional training is carried out through: the development of a holistic aims system, consisting of appropriate categories and successive levels (hierarchy), which is called pedagogical taxonomy; creating the clearest, understandable description of the purposes of the educational process [9].

Agree with the opinion of I. Androschuk [10] that for the aims setting effectiveness, the basic requirements for the aim formulation should be taken into account: clarity, hierarchy and diagnostics. Aim clarity is determined by the accuracy of ideas about the expected result of activities, judgments about the objective and subjective conditions of the aim, opinions about the reality and unreality of the purposes. It is important that during the 
process of intending primary schools teachers' foreign language communicative competence formation on specialty 013 Primary Education it is necessary to transform external aims into internal, i.e. change them into the motives of activities, based on internal needs and interests of future professionals. Aim hierarchy is characterized by the ability to identify at each stage the main (strategic) purposes and subordinate it to others. Stages in achieving strategic aims are subordinated tactical goals. The goals that describe the desired result at the moment are called operational (or working). They are subjected to tactical goals. Aim diagnostics (measurability) involves the presentation of their results, which are determined by qualitative and quantitative characteristics that make it possible to present the product of activity in the form of external features that can be recognized and measured.

It should be noted, that it is necessary to formulate the aim of the intending primary school teachers' foreign language communicative competence development in accordance with a clear hierarchy, which agrees on all levels of aims presentation. Particular attention should be paid to the relationship between teaching and learning aims. This will ensure the understanding and perception of the goals by students and their further successful implementation in the educational process.

In order to ensure the diagnostics and clarity of the purposes, a hierarchy of the aims should be built, within which the levels and categories of aims are clearly defined, which allows to describe them specifically.

Based on the taxonomy of B. Bloom [11], we modified the hierarchy of learning outcomes, formulated in terms of activities in the following areas: in the cognitive area (based on key categories: knowledge, understanding, application of knowledge, analysis, synthesis and evaluation); in the value-motivational sphere (on the basis of categories: educational orientation, social response and communicativeness, value orientation, value organization and conceptualization, value determination); in the psychomotor (activity) sphere (on the basis of categories: imitation, reproduction of manipulations, achievement of accuracy, combination, naturalization) [7].

We are impressed by the opinion of O. Radkevych [12], who distinguishes the aims according to time limits: strategic, reflecting the long-term focus of professional activity on the result; tactical ones are those that determine the medium term; operational are implemented in the near future.

We agree that all three groups of aims are interconnected, and their distribution is conditional. However, the use of such an orderly system of goals makes it possible to identify the tasks: ones, which need to be addressed first, and ones, which need to be realized over a period of time; to indicate the students clear guidelines for their educational activities; to form the results of educational activities that can be objectively evaluated.

In order to define the purposes of intending primary school teachers' foreign language communicative competence development, we studied the educational programs of Bachelor degree in Ukrainian pedagogical higher educational establishments on specialty 013 Primary education and analyzed the experience on teaching English to intending primary school teachers. Therefore, we can describe the results of our study.

\section{Results and discussions}

The hierarchy of learning outcomes substantiated above and the competence approach to professional training of intending primary school teachers gave us a possibility to determine three stages of designing the aims of intending primary school teachers' foreign language communicative competence development: establishment of strategic (general) aim, its concretization in tactical purposes and formulation of operational goals.

To schematically represent the hierarchy of the aims of intending primary school teachers' foreign language communicative competence development, the "Aim tree" method was used, which allows to display the hierarchical structure of the aims by dividing the overall goal into sub-goals, which, in turn, are divided into new sub-goals, etc. This method is based on the functionalsubstantive principle of the system approach, substantiated by V. Marihodov [13]. Applying this method to create a system of the aims of intending primary school teachers' foreign language communicative competence development, in the study we distinguish in the "Aim tree" the following rank hierarchy: general (strategic) aim (level 1); tactical purposes (level 2); operational objectives (level 3).

By designing all the aims graphically at the appropriate levels, we get "Aim tree", which is turned down with the crown, and the overall aim is at the highest level - the top of the tree, that is shown in Fig. 1.

In order to clarify purposes, mentioned in Fig. 1, we'll describe them.

\section{Tactical purposes:}

\section{Cognitive purposes:}

A1 - mastering the phonetic, grammar and lexical system of a foreign language;

A2 - forming of innovative professional and pedagogical knowledge about the theoretical and methodological foundations of the foreign language communicative competence, its concept and structure;

A3 - mastering the professional foreign language terminology;

A4 - forming of knowledge about strategies and tactics of foreign language interaction in the educational process;

A5 - forming of knowledge about the types of barriers and conflicts during foreign language communication, the reasons for their occurrence and the ways to eliminate them;

A6 - forming of knowledge about the peculiarities of interaction with the subjects of the educational process;

A7 - forming of knowledge about the means of teaching foreign languages and requirements for their development and methods of their using;

A8 - acquaintance with cultural features of the countries, whose language is studied.

\section{Developmental purposes:}

B1 - formation of the intending primary school teachers' value orientations system, aimed at the formation and development of their own foreign language communicative competence;

B2 - developing reflection and self-educational activities, aimed at foreign language communicative competence formation; 
B3 - forming of the need for continuous professional and personal improvement of the foreign language communicative competence;

B4 - forming of skills to organize self-educational activities in order to increase the level of own foreign language communicative competence, to choose the best forms and methods;

B5 - providing the conditions for self-realization of a future primary school teacher's personality in the process of foreign language communication;

B6 - having moral and ethical norms of interaction during foreign language communication; humanistic orientation, social responsibility in the process of foreign language communication;

B7 - forming of respect for the participants of the interaction, regardless of their religion, nationality and views; attitude to students as the highest value; recognition of the students' right to freedom and happiness, free development and manifestation of their abilities in the process of learning a foreign language; formation of the ability to show cooperation respect, tolerance and justice for the student, the ability to empathize;

B8 - forming of the future primary school teachers' behavior culture, the development of social activity, the ability to evoke positive emotions and feel satisfaction with the process and result of foreign language pedagogical interaction;

B9 - forming the ability to maintain self-control; formation of skills to exercise self-regulation of their emotions and behavior.

Strategic aim: intending primary school teachers' foreign language communicative competence development

\section{Tactical purposes}

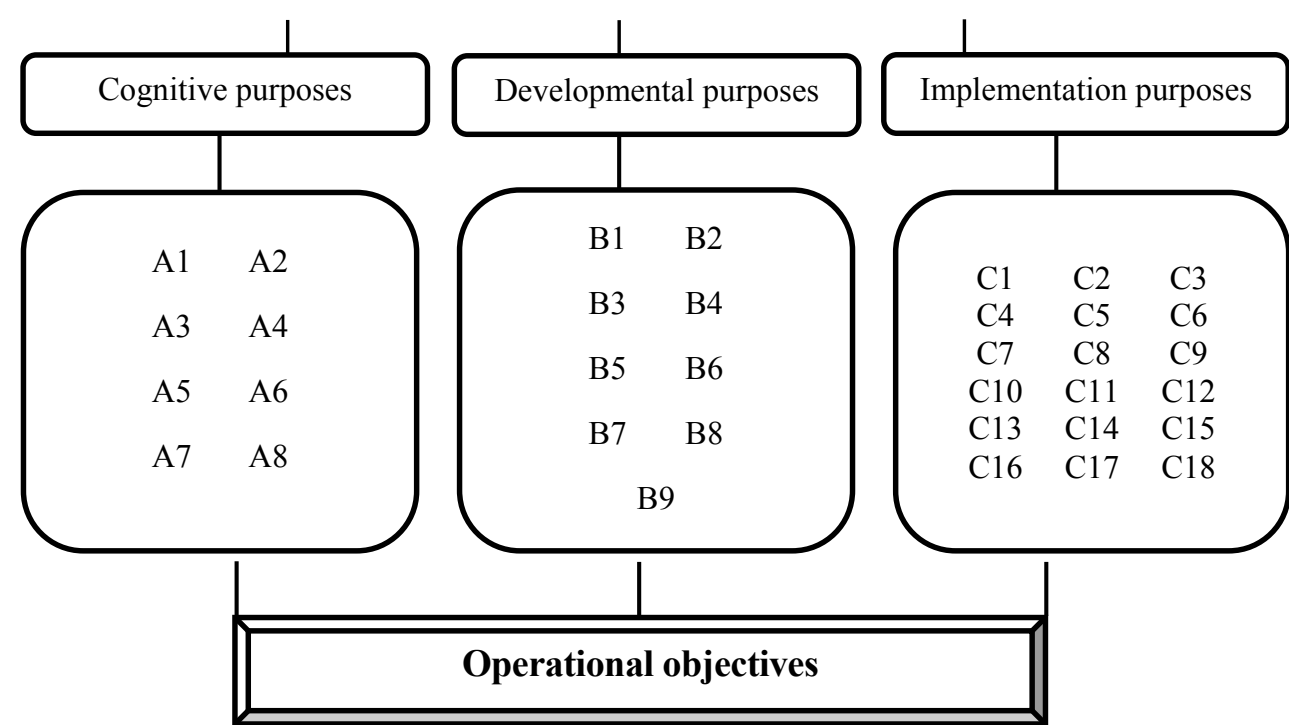

Fig. 1. "Aim Tree" of intending primary school teachers' foreign language communicative competence development

\section{Implementation purposes:}

$\mathrm{Cl}$ - forming the skills to interpret educational information from the position of a student; forming the skills to predict the development of the student's personality with a focus on the positive process of foreign language communicative competence development;

C2 - forming critical thinking, developing logical thinking operations, erudition during foreign language communication;

C3 - forming the ability to choose the optimal strategy and tactics of foreign language interaction depending on the purpose and individual characteristics of its participants;

$\mathrm{C} 4$ - forming the skills of foreign language communication with participants of the educational process;

C5 - forming the ability to choose effective methods of pedagogical influence for the realization of educational aims;
C6 - forming the ability to use pedagogical technologies in the foreign language educational process;

C7 - forming the skills to monitor foreign language interaction and its results;

C8 - forming intercultural communication skills;

C9 - forming the ability to correctly solve non-standard pedagogical situations in a foreign language;

C10 - forming the skills to organize and manage pedagogical interaction in classroom and extracurricular foreign language activities;

C11 - forming the skills to develop and draw up the necessary educational and methodical documentation, teaching aids in a foreign language.

$\mathrm{C} 12$ - forming the ability to present oneself in a foreign language as a specialist, the methodological developments. 
$\mathrm{C} 13$ - forming the skills to identify and eliminate the causes of conflicts in the process of foreign language interaction with participants during the educational process;

C14 - forming the skills of developing multimedia presentations and means of control of educational achievements of primary school pupils in a foreign language;

$\mathrm{C} 15$ - forming the skills to generate the latest ideas, to solve problem situations quickly; mastering the methods of pedagogical creative activity in a foreign language;

C16 - forming the skills in designing the professional foreign language portfolio as one of the means of self-presentation;

$\mathrm{C} 17$ - forming the ability to analyze the results of foreign language educational activities, identify mistakes and successes;

C18 - forming the skills to analyze and evaluate the effectiveness and feasibility of their own pedagogical decisions and educational tasks in a foreign language.

\section{Conclusions}

The results of this study support the idea that the content of professional training should be based on the system of educational aims in order to master preservice primary school teachers' foreign language communicative competence development. Our research leads to the conclusions:

1) there were defined the basic requirements for the aim formulation: aim clarity, aim hierarchy and aim diagnostics;

2) the process of aims setting of pre-service primary school teachers' foreign language communicative competence development was described in the paper. The aim hierarchy should cover the aims system of preservice primary school teachers' foreign language communicative competence development, which include 3 levels of purposes: general (strategic) aim (level 1); tactical (level 2) that are presented with cognitive, developmental and implementation purposes; operational objectives (level 3);

3) the hierarchy of educational aims development for pre-service primary school teachers foreign language communicative competence was presented graphically by means of "Aim tree", which is turned down with the crown, and the overall aim is at the highest level, at the top of the tree.

\section{References}

1. Lazareva, T. A. (2014). Teoretychni i metodychni zasady pidhotovky maibutnikh inzheneriv-tekhnolohiv kharchovoi haluzi do tvorchoi profesiinoi diialnosti. Kharkiv, 625 .

2. Halliday, M. A. K.; Webster, J. J. (Ed.) (2016). Aspects of Language and Learning. New York: Springer Heidelberg, 148.

3. Konovalenko, T. V., Goncharova, O. A. (2018) Future English Language Teachers' Life Skills Development in Methodology Course. Studies in comparative education, 1, 98-104.

4. Levytes, D. H. (2016). Avtodydaktyka. Shkolnie tekhnolohyy, 5, 101-106. Available at: https://rucont.ru/efd/589600

5. Radkevych, V. O. (2016). Teoretychni ta metodychni zasady rozvyku profesiioi osvity i navchannia: rezultaty, problemy, perspektyvy. Naukovyi visnyk Instytutu profesiino-tekhninoi osvity NAPN Ukrainy. Profesiina pedahohika, 11, 5-22.

6. Nikolaieva, S. Yu. (2016). Mizhkulturna inshomovna osvita v Ukraini: kliuchovi problemy. Inozemni movy, 86 (2), 3-9.

7. Metodychni rekomendatsii shchodo rozroblennia standartiv vyshchoi osvity. Available at: https://aw.chnu.edu.ua/ metodychni-rekomendatsii-shchodo-rozroblennia-standartiv-vo/

8. Malafiik, I. V., Kryvko, M. P. (2016). Yednist upravlinskoho ta dydaktychnoho tsykliv yak osnova formuvannia subiekta navchalnoho piznannia. Onovlennia zmistu, form ta metodiv navchannia i vykhovannia v zakladakh osvity, 13 (56), $113-116$.

9. Klarin, M. (2016). Conceptual challenges in understanding innovative education in organizational context. International Journal of Cognitive Research in Science, Engineering and Education, 4 (1), 67-71. doi: http://doi.org/10.5937/ijcrsee1601067k

10. Androshchuk, I. V. (2017). Teoretychni i metodychni osnovy pidhotovky maibutnikh uchyteliv trudovoho navchannia ta tekhnolohii do pedahohichnoi vzaiemodii u profesiinii diialnosti. Kyiv, 641.

11. Bloom, B. S. (1956). Taxonomy of Educational Objectives, the classification of educational goals: Handbook I. The Cognitive Domain. New York: David McKay, 207. Available at: http://www.psy.gla.ac.uk/ steve/best/bloom.html Last accessed: 26.02.2019

12. Radkevych, O. (2021). Communication in project activities of the teaching staff in vocational education institutions. Professional Pedagogics, 2 (21), 129-136. doi: http://doi.org/10.32835/2707-3092.2020.21.129-136

13. Marihodov, V. K. (2014). Metody zakhystu navchalnoi informatsii v merezhakh dystantsiinoi osvity. Novi tekhnolohii navchannia, 80, 179-182.

14. Koshuk, O. B. (2017). Kontseptualni aspekty tsilespriamovanoho formuvannia profesiinoi kompetentnosti maibutnikh inzheneriv z mekhanizatsii silskoho hospodarstva. Suchasni problemy ta perspektyvy rozvytku psykholohii i pedahohiky. Kyiv: Tavriiskyi natsionalnyi universytet imeni V. I. Vernadskoho, 95-98.

Received date 21.12.2020

Accepted date 26.01.2021

Published date 30.01.2021

Tamara Bondar, Doctor of Pedagogical Sciences, Associate Professor, Head of Department, Department of Pedagogy of Preschool, Primary Education and Educational Management, Mukachevo State University, Uzhgorodska str., 26, Mukachevo, Ukraine, 89608

E-mail: tamara_bondar@yahoo.com 